\title{
Ephippia belonging to Ceriodaphnia Dana, 1853 (Cladocera: Anomopoda: Daphniidae) from the Lower Cretaceous of Australia
}

\author{
Thomas A. Hegna and Alexey A. Kotov
}

\begin{abstract}
The first fossil ephippia (cladoceran exuvia containing resting eggs) belonging to the extant genus Ceriodaphnia (Anomopoda: Daphniidae) are reported from the Lower Cretaceous (Aptian) freshwater Koonwarra Fossil Bed (Strzelecki Group), South Gippsland, Victoria, Australia. They represent only the second record of (pre-Quaternary) fossil cladoceran ephippia from Australia (Ceriodaphnia and Simocephalus, both being from Koonwarra). The occurrence of both of these genera is roughly coincident with the first occurrence of these genera elsewhere (i.e., Mongolia). This suggests that the early radiation of daphniid anomopods predates the breakup of Pangaea. In addition, some putative cladoceran body fossils from the same locality are reviewed; though they are consistent with the size and shape of cladocerans, they possess no cladoceran-specific synapomorphies. They are thus regarded as indeterminate diplostracans.
\end{abstract}

Thomas A. Hegna. Department of Geology, Western Illinois University, Macomb, IL 61455, USA. tahegna@wiu.edu

Alexey A. Kotov. A.N. Severtsov Institute of Ecology and Evolution, Leninsky Prospect 33, Moscow 119071, Russia and Kazan Federal University, Kremlevskaya Str.18, Kazan 420000, Russia. alexey-akotov@yandex.ru

Keywords: Crustacea; Branchiopoda; Cladocera; Anomopoda; Daphniidae; Cretaceous.

Submission: 28 March 2016 Acceptance: 22 September 2016

\section{INTRODUCTION}

Water fleas (Crustacea: Cladocera) are small, soft-bodied branchiopod crustaceans and are a diverse and ubiquitous component of inland aquatic communities (Dumont and Negrea, 2002). Despite this, their pre-Quaternary fossil record is very sparse - owing to the fact that they are universally small (majority are less than $1 \mathrm{~mm}$, a few are about 5-6 $\mathrm{mm}$ long) and are hard to identify as compression fossils. There are intriguing indica- tions that the sparse known fossil record does not correlate with a meager past diversity. The rarity of the cladoceran fossils is probably an artifact, a result of insufficient efforts to find them in known and new palaeontological collections (Kotov, 2007). Over the past two decades, our knowledge of fossil cladocerans has increased dramatically due to the close examination of ancient lacustrine sediments by cladocerans experts. The result of this has been a flurry of new species and the dis-

Hegna, Thomas A. and Kotov, Alexey A. 2016. Ephippia belonging to Ceriodaphnia Dana, 1853 (Cladocera: Anomopoda: Daphniidae) from the Lower Cretaceous of Australia. Palaeontologia Electronica 19.3.40A: 1-9

palaeo-electronica.org/content/2016/1623-cretaceous-ephippia 
covery of two extinct, order-level clades of cladocerans, the Cryptopoda Kotov, 2007 and the Proanomopoda Kotov, 2013 (Kotov, 2007, 2013).

Two of the four major orders of cladocerans, Haplopoda Sars, 1865 and Onychopoda Sars, 1865 , have no pre-Quaternary fossil record, and a third order, Ctenopoda Sars, 1865 (aside from Quaternary records) is only known from four midto late Mesozoic Mongolian and Asian Russia lacustrine localities (Kotov, 2007; Kotov and Korovchinsky, 2006). The most diverse modern order of cladocerans, the Anomopoda Sars, 1865, has a meager representation in the fossil record with a handful of species known from body (excluding ephippia) fossils (Smirnov, 1992; Kotov, 2007, 2009a, 2009b, 2013). The status of the purported Paleozoic fossil 'anomopod' Ebullitiocaris Anderson, Crighton, and Hass, 2004 reported by Womack et al. (2012) is highly dubious as the position of the "second antennae" relative to the carapace conflicts with the body plan of all other known cladocerans - living or extinct.

Anomopod egg cases or ephippia (dormant embryos), provide another glimpse into their fossil record-one with a better preservation potential than fossils of the body. Ephippia enclose resting eggs (typically the product of sexual reproduction) encased in a protective outer covering formed from part of the dorsal chitinous carapace of the mother (Dumont and Negrea, 2002). Anomopods are the only group of cladocerans to produce such cases (Kotov, 2009a, 2013). Some major groups of living anomopods (i.e., from the families Daphniidae Straus, 1820 and Moinidae Goulden, 1968) produce characteristic ephippia that are diagnostic down to the genus level (Berner, 1985; Scourfield, 1902; Kokkinn and Williams, 1987; Lu, 2001; Vanderkerhove et al., 2004; Mergeay et al., 2005).

The aim of this study is to update the taxonomic status of some cladoceran remains from the freshwater lacustrine sediments of the Lower Cretaceous Koonwarra Fossil Bed, Australia.

\section{MATERIAL AND METHODS}

Although ephippia have a higher preservational potential than cladoceran body fossils, they are not used to describe modern species - in fact, they are undescribed for a number of extant species (Kotov, 2013). However, representative ephippia are known from many cladoceran genera, and some of those genera are characterized by distinctive ephippial morphotypes that often allow for identification at the genus level (Kokkin and Williams, 1987, Vanderkerhove et al., 2004; Mergeay et al., 2005; Szeroczyńska and Sarmaja-Korjonen, 2007). Thus, the fossils discussed herein are kept in open nomenclature at the genus level. The specimen was found while one of the authors (TAH) was reviewing the figured specimens of the anostracan species from the Koonwarra Fossil Bed (Jell and Duncan, 1986, further details below under Occurrence). Specimens were photographed with a Leica and Zeiss binocular microscope and digital camera. The contrast was enhanced using Adobe Photoshop. Drawings were produced using Adobe Illustrator. The modern specimens of Ceriodaphnia sp. and Daphnia magna were lyophilized (freezedried), coated with gold, and imaged with a JEOL$840 \mathrm{~A}$ scanning electron microscope.

\section{SYSTEMATIC PALAEONTOLOGY}

\author{
Phylum ARTHROPODA Latreille, 1829 \\ Subphylum CRUSTACEA Brünnich, 1772 \\ Class BRANCHIOPODA Latreille, 1817 \\ Subclass DIPLOSTRACA Gerstaecker, 1866 \\ ?Diplostraca indet. \\ Figure 1.3-1.4
}

Material. NMVP 109450 and NMVP 109462 from the Museum of Victoria, Australia.

Description. Only unclear impressions are found. Some traces of the head (Figure 1.3; hd), valves (vv), postabdomen (pd), antennae II (all), and thoracic limbs (tl) are observable, but no detail could be unambiguously identified. In some impressions, there are obvious mandibles (Figure 1.4; $\mathrm{md}$ ) of the branchiopod-type, asymmetrical, with bent distal end supplied with mastiscatory surface (Figure 2.2). No further details are recognizable. In addition, the specimens seem to be strongly deformed, and may represent either molted exoskeletons or carcasses that had undergone significant decay of soft tissue prior to preservation.

Discussion. Jell and Duncan (1986) reported on several fossil specimens identified as daphniid body fossils. However, they list no daphniid-specific synapomorphies to support their identifications. Furthermore, many of their interpretive drawings suggest a chydorid-like body shape (round with a pointed rostrum) rather than a daphniid-like shape (more elliptical, rounded head shield, often with a posterior apical spine). Size and shape are really the only features that can be unambiguously described from these specimensand they are nearly impossible to translate into unambiguous synapomorphies. The specimens described above could also belong to Ceriodaphnia (family Daphniidae), but no real evidence for this could be found; the impressions are too 

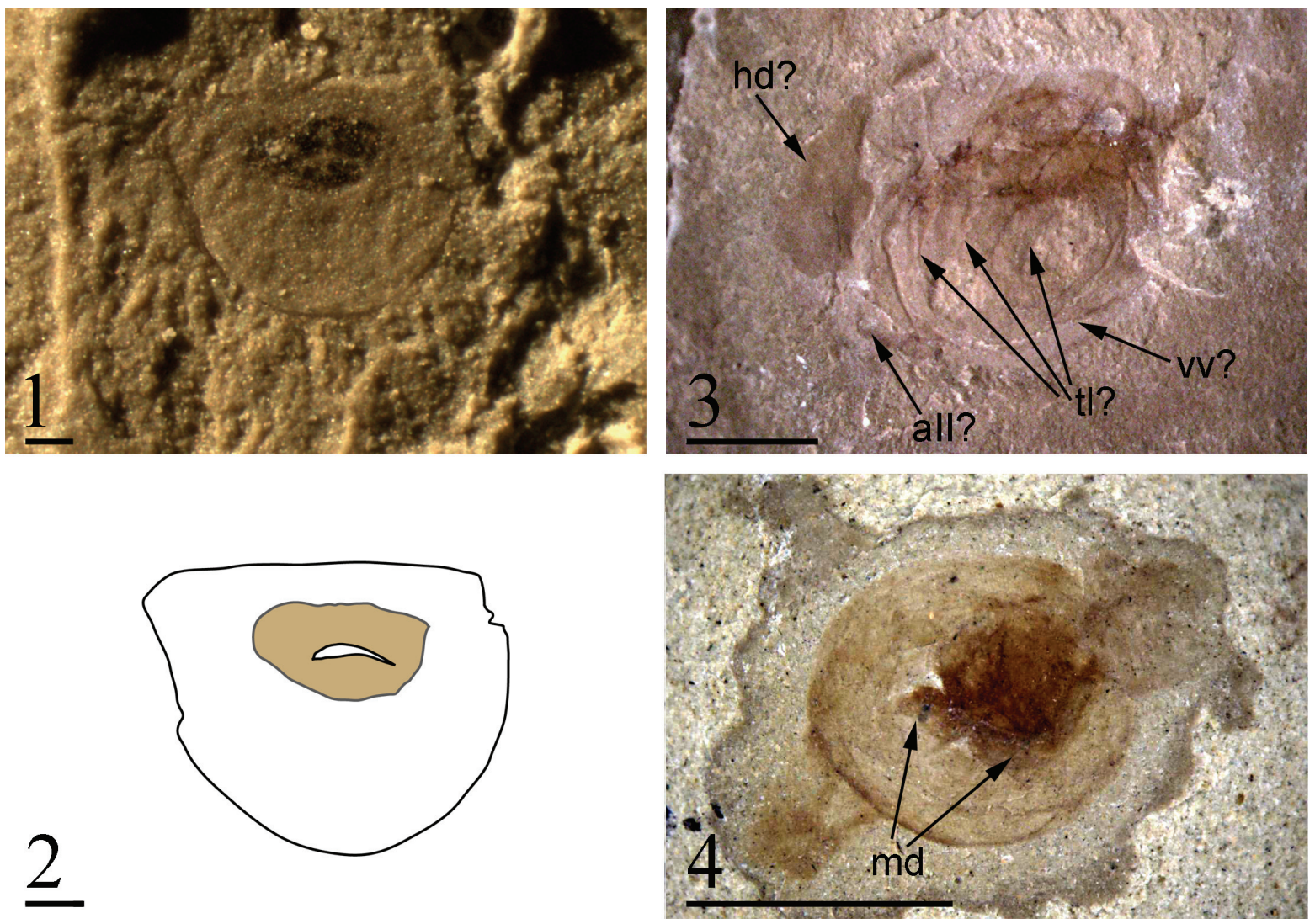

FIGURE 1. Fossil diplostracan remains from Koonwarra. 1, An image of a fossil ephippium belonging to Ceriodaphnia sp. from the Koonwarra Fossil Beds (photographed with obliquely directed light), NMV P332637, 2, Interpretive drawing of Figure 1.1, scale bar for 1-2 equals $0.1 \mathrm{~mm}$. 3, Diplostracan indet, NMV P109450 (figure $70 \mathrm{G}$ and $71 \mathrm{C}$ in Jell and Duncan, 1986), See Figure 1.4 for scale bar. 4, Diplostracan indet, NMV P109462 (figure 70H and 71E in Jell and Duncan, 1986). Scale bar in 1.4 applies to 1.3 as well. Scale bar for $1.3-4$ equals $1 \mathrm{~mm}$. Abbreviations: all - antenna II; hd - head; $\mathrm{tl}$ - thoracic limbs; vv - valves.

deformed and badly preserved. The specimens could easily belong to other anomopod genera, ctenopod cladocerans, or possibly even juvenile clam shrimp (Spinicaudata, Laevicaudata, or Cyclestherida).

Occurrence. Lower Cretaceous Koonwarra Fossil Bed, Strzelecki Group, south Gippsland, Victoria, Australia. The age of this bed is constrained to a maximum age of between $115 \pm 6 \mathrm{Ma}$ and $118 \pm 5 \mathrm{Ma}$ (Aptian) by fission track radiometric ages derived from volcanogenic apatites isolated from above and below the fossil-bearing strata (Lindsay, 1982, see Drinnan and Chambers, 1986). This is consistent with age estimates derived from palynological data (Dettmann, 1986; Drinnan and Chambers, 1986).

Superorder CLADOCERA Latreille, 1829

Order ANOMOPODA Sars, 1865

Family DAPHNIIDAE Straus, 1820

Genus CERIODAPHNIA Dana, 1853
Ceriodaphnia sp.

Figure 1.1-1.2, Appendix 1

Material. NMV P332637, Museum of Victoria. The rock which contains this specimen also contains fossil anostracans (see Jell and Duncan, 1986, figure 73A). Additional specimens are figured in the Appendix 1.

Description. Ephippium shaped as half an oval bisected along the short axis, straight dorsal margin, length $=0.6 \mathrm{~mm}$, height/length $=0.8$, posterior margin is symmetrically curved with a possible faint rim preserved around the ventral margin. No ornamentation is preserved, as in some extant species of Ceriodaphnia (Figure 2.1). Single oval-shaped egg, long axis of the egg oriented parallel to the dorsal margin. Maximum egg length/max ephippial length $=0.5$ (assuming that the carbonaceous material represents the true size of the egg). The ephippium is preserved mostly as an impression, with a small amount of carbonaceous material pre- 

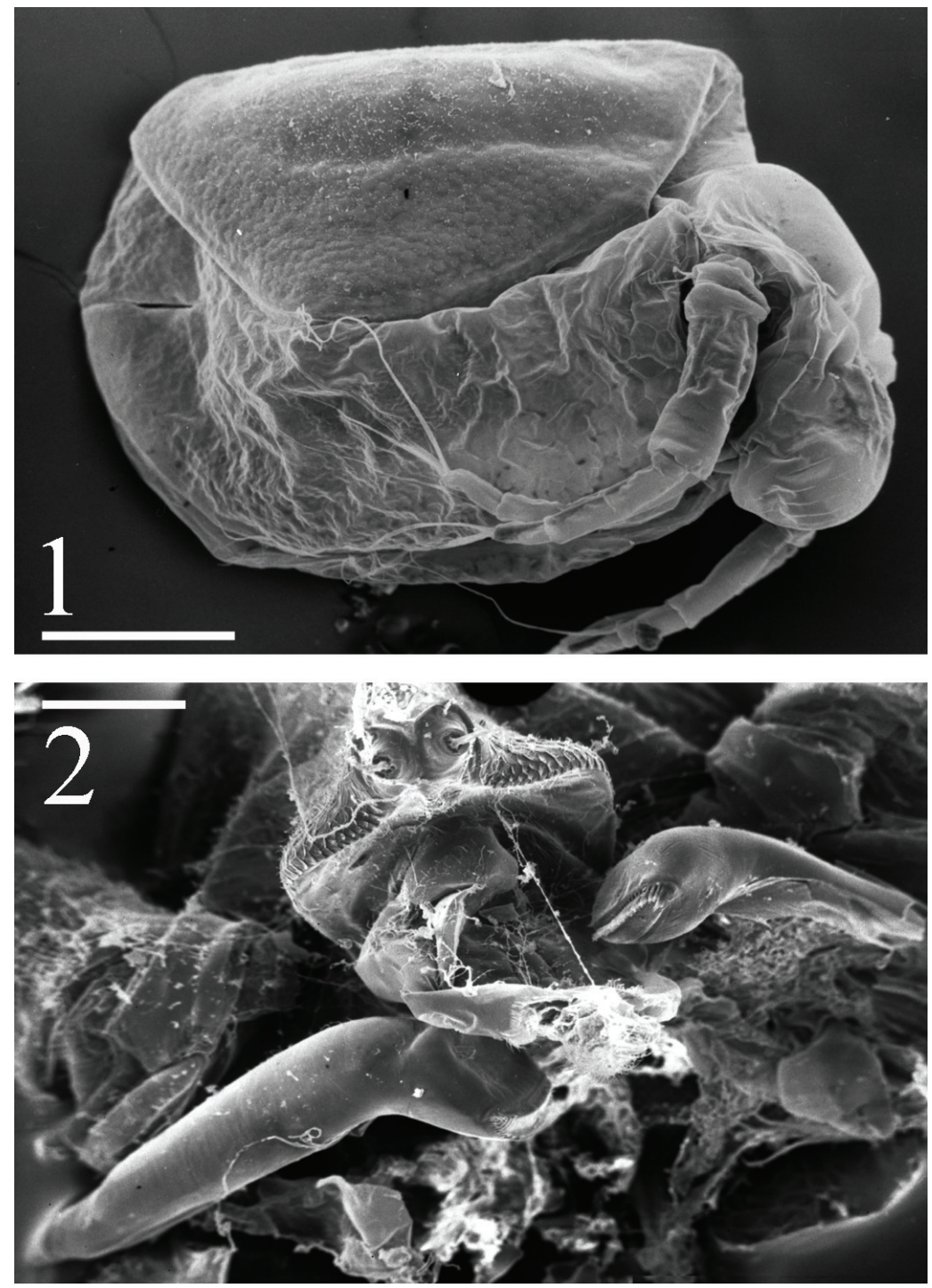

FIGURE 2. Modern Ceriodaphnia sp. 1, Scanning electron microscope image of a modern ephippium-bearing Ceriodaphnia sp. female (collected from Glubokoe Lake, European Russia) prior to releasing the ephippium during molting, ephippium tilted slightly away from angle of photograph, scale bar equals $0.1 \mathrm{~mm}$. 2, Scanning electron microscope image of the mandibles of Daphnia magna, scale bar equals $0.1 \mathrm{~mm}$.

served medially - this may represent the remains of the resting egg.

Discussion. The fossils discussed herein were originally identified as daphniid indet by Jell and Duncan (1986) and were discussed alongside the putative cladoceran body fossils. In their remarks, they speculated that the ephippia they examined possibly belonged to either Simocephalus or Ceriodaphnia (Jell and Duncan, 1986, p. 193). Fryer (1991) revisited Jell and Duncan's (1986) material and demonstrated the presence of Simocephalustype ephippia based on their single egg and asymmetrical lateral outline. A closer examination of the cladoceran ephippia examined by Jell and Duncan
(1986) demonstrate that the genus Ceriodaphnia is also present.

Daphniidae in general have a strongly developed, firm, well-elaborated ephippia (in contrast to chydorids and macrothricids, in daphniids and moinids the ephippiual portion of the female caparace is significantly modified, thickened, supplied with air loculi between internal and external wall), and bearing only 1-2 resting eggs (Kotov, 2013). The symmetrical (in lateral view), half-oval shape of the ephippium coupled with the presence of one extremely large resting egg is characteristic of Ceriodaphnia (see Figure 2.1 for a SEM image of a modern female Ceriodaphnia with ephippium prior 
to moulting). Other lineages within Daphniidae have either different shaped ephippia, have ephippia with two resting eggs, or both (see the discussion in Kotov 2009b, 2013). Simocephalus, from the same locality, has a strongly asymmetric outline (in lateral view) that is like a teardrop shape bisected along the long axis. Among the other single-egg-ephippia cladocerans, chydorids have an ephippium with thin, slightly modified walls (as compared with parthenogenetic female) and curved dorsal margin (Vandekerkhove et al., 2004), and moinids have much more rectangular to elliptical outline with stronger sculpture (Goulden, 1968; Fryer, 1991; Lu, 2001).

In extant daphniids, the ephippium length is normally more than half of the female length, such a relationship would predict an adult female length of about $1 \mathrm{~mm}$. This size is characteristic of many recent species (i.e., C. dubia Richard, 1894, C. reticulata (Jurine, 1820), amongst others, see Flössner, 2000) and is roughly equivalent to the size of the undiagnostic circular fossils identified by Jell and Duncan (1986) as the body fossils of daphniid cladocerans described also above (although plausible as fossil cladocerans, the main cited similarity between the fossils and cladocerans is their size and their circular shape).

The fossil Ceriodaphnia ephippium does not preserve any evidence of sculpture. Among recent species (Hudec, 2010; Kotov, 2013) ephippial sculpture is variable-there are both taxa with ephippia covered by a complicated sculpture and those without any sculpture. Therefore, the ephippium from Koonwara is within the range of variation known from recent species.

Occurrence. Same as above.

\section{CONCLUSIONS}

The ephippia specimens reported here bring the total identified cladoceran fauna from the Koonwarra Fossil Bed to two - representing Ceriodaphnia and Simocephalus (Fryer, 1991). Neither of these genera are endemic to Australia, rather they have a widespread distribution (Smirnov and Timms, 1983). Today in addition to a number of cosmopolitan genera like Ceriodaphnia and Simocephalus, Australia has a unique and highly diverse fauna of cladoceran genera - owing to its long separation from Gondwanaland. In the cladoceran fossil record of Australia, which is restricted to ephippia, there is no trace of this uniqueness (i.e., no known fossils of the modern endemic genera). Both recorded genera are also known from roughly coeval deposits in Mongolia (Ceriodaphnia, see
Kotov, 2009b; Simocephalus, see Smirnov, 1992; Kotov, 2007; Kotov and Taylor, 2011). During the Late Jurassic and Early Cretaceous, Mongolia and Australia occupied opposite hemispheres and were even more separated from one another than they are today. Thus, several daphniid lineages were already widespread by the mid- to late Mesozoic. This implies that the long-range dispersal mechanisms common among cladocerans (i.e., being able to survive passage through the digestive system of a predator, see Mellors, 1975; Proctor, 1964) had probably already originated by the middle Mesozoic. Outside Australia, most of the major clades of anomopod cladocerans had already originated by the end of the Jurassic, according to the ephippial fossil record (see the table in Appendix 2).

\section{ACKNOWLEDGEMENTS}

This study is supported by the Program of the Russian Government Program of Competitive Growth of Kazan Federal University. R. Schmidt (Museum of Victoria) is gratefully acknowledged for his help in loaning the specimens for study. S. Heads and J. Thomas (Illinois Natural History Survey) aided with photography. H. Dumont, D. Horne, P. Jell, and several anonymous reviewers helped hone the ideas in this paper.

\section{REFERENCES}

Anderson, L.I., Crighton, W.R.B., and Hass, H. 2004. A new univalve crustacean from the Early Devonian Rhynie chert hot-spring complex. Transactions of the Royal Society of Edinburgh: Earth Sciences, 94(for 2003):355-369.

Berner, D.B. 1985. Morphological differentiation among species in the Ceriodaphnia cornuta complex (Crustacea, Cladocera). Verhandlungen der Internationalen Vereinigung für Theoretische und Angewandte Limnologie, 22:3099-3103.

Brünnich, M.T. 1772. Zoologiæ fundamenta prælectionibus academicis accomodata. Grunde i Dyrelaeren. Fridericus Christianus Pelt, Copenhagen \& Leipzig.

Dana, J.D. 1853. Crustacea. Part II. Daphnioidea. United States Exploring Expedition during the years 1838, 1839, 1840, 1841, 1842 under the command of Charles Wilkes, U.S.N. 14:1262-1277. C. Sherman, Philadelphia.

Dettmann, M.E. 1986. Early Cretaceous palynoflora of subsurface strata correlative with the Koonwarra Fossil Bed, Victoria. Memoirs of the Association of Australasian Palaeontologists, 3:79-110.

Drinnan, A.N. and Chambers, T.C. 1986. Flora of the Lower Cretaceous Koonwarra Fossil Bed (Korumburra Group), South Gippsland, Victoria. Memoirs of 
the Association of Australasian Palaeontologists, 3:1-77.

Dumont, H.J. and Negrea, S.V. 2002. Branchiopoda. Guides to the Identification of the Microinvertebrates of the Continental Waters of the World, Volume 19. Backhuys Publishers, Leiden.

Flössner, D. 2000. Die Haplopoda und Cladocera (ohne Bosminidae) Mitteleuropas. Backhuys, Leiden.

Fryer, G. 1991. A daphnid ephippium (Branchiopoda: Anomopoda) of Cretaceous age. Zoological Journal of the Linnean Society, 102:163-167.

Gerstaecker, A. 1866. Crustacea (Erste Hälfte). Die Klassen und Ordnungen der Thier-Reichs, Bd. 5 (Arthropoda). Abt. 1. Akad. Verlag, Leipzig.

Goulden, C.E. 1968. The systematics and evolution of the Moinidae. Transactions of the American Philosophical Society, New Series, 58:1-101.

Hudec, I. 2010. Anomopoda, Ctenopoda, Haplopoda, Onychopoda (Crustacea: Branchiopoda). Fauna Slovenska III. VEDA, Bratislava.

Jell, P. A. and Duncan, P.M. 1986. Invertebrates, mainly insects, from the freshwater, Lower Cretaceous, Koonwarra Fossil Bed (Korumburra Group), South Gippsland, Victoria. Memoirs of the Association of Australasian Palaeontologists, 3:111-205.

Jurine, L. 1820. Histoire des Monocles, qui se trouvent aux environs de Génève. J.J. Paschoud, Génève.

Kokkinn, M.J. and Williams, W.D. 1987. Is ephippial morphology a useful taxonomic descriptor in the Cladocera? An examination based on a study of Daphniopsis (Daphniidae) from Australian salt lakes. Hydrobiologia, 145:67-73.

Kotov, A.A. 2007. Jurassic Cladocera (Crustacea, Branchiopoda) with a description of an extinct Mesozoic order. Journal of Natural History, 41:13-37.

Kotov, A.A. 2009a. A revision of the extinct Mesozoic family Prochydoridae Smirnov, 1992 (Branchiopoda: Cladocera) with a discussion of its phylogenetic position. Zoological Journal of the Linnean Society, 155:253-265.

Kotov, A.A. 2009b. New finding of Mesozoic ephippia of the Anomopoda (Crustacea: Cladocera). Journal of Natural History, 43:523-528.

Kotov, A.A. 2013. Morphology and phylogeny of the Anomopoda (Crustacea: Cladocera). KMK Press, Moscow.

Kotov, A.A. and Korovchinsky N.M. 2006. First record of fossil Mesozoic Ctenopoda (Crustacea, Cladocera). Zoological Journal of the Linnean Society, 146:269274.

Kotov, A.A. and Taylor, D.J. 2011. Mesozoic fossils (>145 Mya) suggest the antiquity of the subgenera of Daphnia and their coevolution with chaoborid predators. BMC Evolutionary Biology, 11:129. doi:10.1186/ 1471-2148-11-129.

Lai, X.-R. 1990. Fossil cladoceran ephippia from the Cretaceous of the Songliao Basin, northeast China. Acta Micropalaeontologica Sinica 7:77-81.
Latreille, P.A. 1817. Les Crustacés, les Arachnides, les Insectes. Le Règne Animal Distribué d'après son Organisation, pour Servir de Base a l'Histoire Naturelle des Animaux et d'Introduction a l'Anatomie Comparée, vol. 3. Deterville, Paris.

Latreille, P.A. 1829. Les Crustacés, les Arachnides et les Insectes, Distribués en Familles Naturelles. Déterville, Paris.

Lindsay, N.M. 1982. The burial history of the Strzelecki Group sandstones, S.E. Australia: a petrographic and fission track study. M.Sc. Thesis, University of Melbourne, Melbourne.

Lu, K.-H. 2001. Morphology and ultrastructure of the ephippia of some Cladocera (Crustacea). Acta Zoologica Sinica, 47:565-572.

Lutz, H. 1991. Autochthone aquatische Arthropoda aus dem Mittel-Eozän der Fundstätte Messel (Insecta: Heteroptera; Coleoptera; cf. Diptera-Nematocera; Crustacea: Cladocera). Courier Forschungsinstitut Senckenberg, 139:119-125.

Mellors, W.K. 1975. Selective predation of ephippial Daphnia and the resistance of ephippial eggs to digestion. Ecology, 56:974-980.

Mergeay, J., Verschuren, D., and De Meester, L. 2005. Daphnia species diversity in Kenya, and a key to the identification of their ephippia. Hydrobiologia, 542:261-274.

Proctor, V.W. 1964. Viability of crustacean eggs recovered from ducks. Ecology, 45:656-658.

Richard, J. 1894. Entomostracés recueillis par M.E. Modigliani dans le lac Toba (Sumatra). Annali del Museo civico di storia naturale di Genova, 14:565578.

Sars, G.O. 1865. Norges Ferskvandskrebsdyr forste afsnit Branchiopoda. I. Cladocera Ctenopoda (Fam. Sididae \& Holopedidae). Brøgger and Christie's Bogtrykkeri, Christiania, Denmark.

Scourfield, D.J. 1902. The ephippia of the lynceid Entomostraca. Journal of the Quekett Microscopical Club, series 2, 8:217-244.

Smirnov, N.N. 1992. Mesozoic Anomopoda (Crustacea) from Mongolia. Zoological Journal of the Linnean Society, 104:97-116.

Smirnov, N.N. and Timms, B.V. 1983. A revision of the Australian Cladocera (Crustacea). Records of the Australian Museum, Supplement, 1:1-132.

Straus, E.H. 1820. Mémoire sur les Daphnia de la classe des Crustacés. Mémoire du Muséum d'Histoire Naturelle, Paris, 5:380-425.

Szeroczyńska, K. and Sarmaja-Korjonen, K. 2007. Atlas of Subfossil Cladocera from Central and Northern Europe. Friends of the Lower Vistula Society, Świecie.

Vandekerkhove, J., Declerck, S., Vanhove, M., Brendonck, L., Jeppesen, E., Conde Porcuna, J.M.C., and De Meester, L. 2004. Use of ephippial morphology to assess richness of anomopods: potentials and pitfalls. Journal of Limnology, 63:75-84. 
Womack, T., Slater, B.J., Stevens, L.G., Anderson, L.I., and Hilton, J. 2012. First cladoceran fossils from the Carboniferous: Palaeoenvironmental and evolution- ary implications. Palaeogeography, Palaeoclimatology, Palaeoecology, 344-345:39-48. doi: 10.1016/ j.palaeo.2012.05.012. 


\section{APPENDIX 1}

Additional ephippia from Koonwarra. 1-12, Ceriodaphnia sp. All scale bars $=200 \mu \mathrm{m} .1$, NMV P332699. 2, NMV P332700. 3, NMV P332698. 4, NMV P332702. 5, NMV P332701. 6, NMV P109499B. 7, NMV P332693. 8, NMV P332695. 9, NMV P332692. 10, NMV P332696. 11, NMV P332694. 12, NMV P109500.
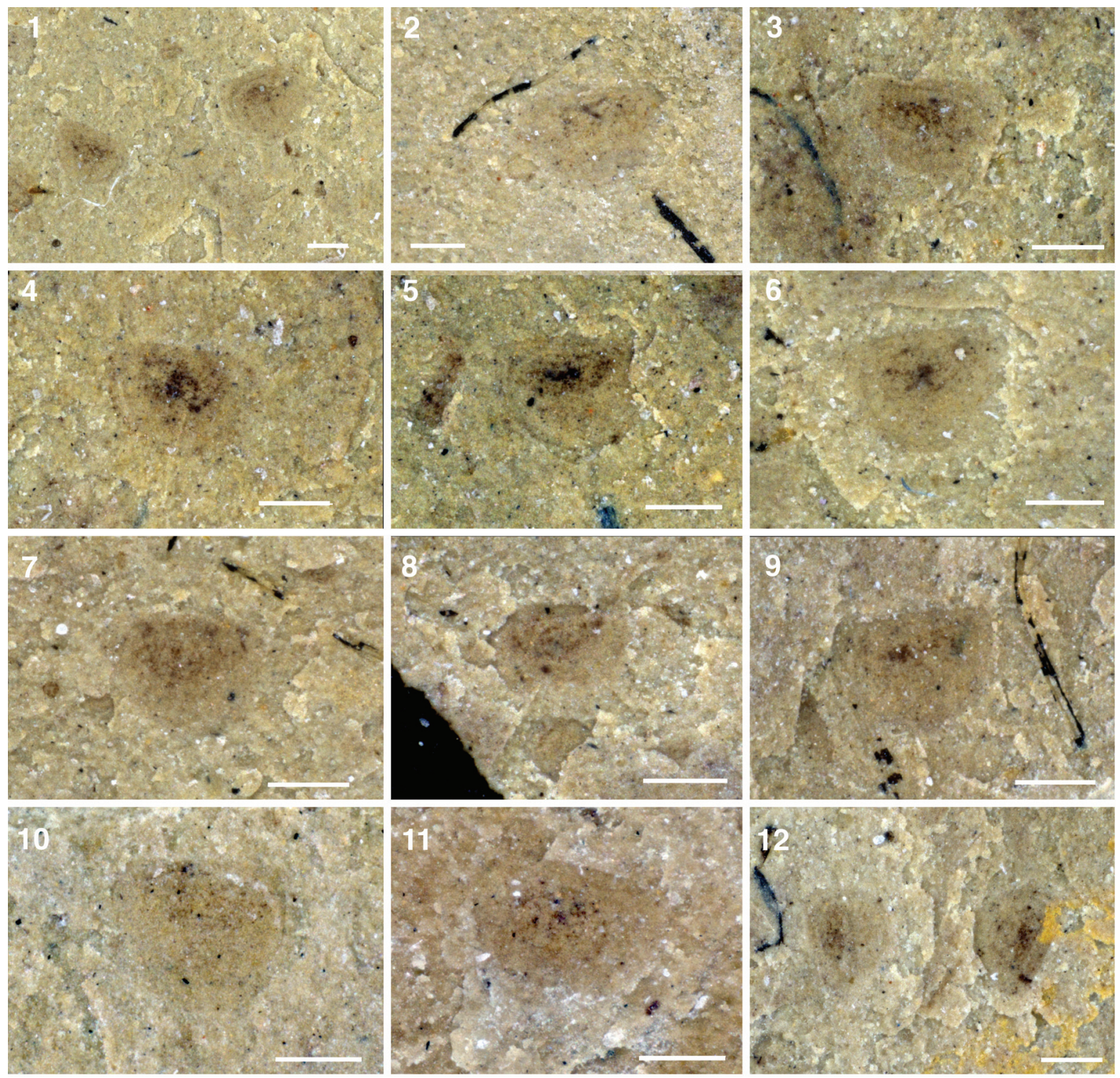


\section{APPENDIX 2.}

Table of the oldest known ephippial fossils for different cladoceran clades. Excludes Quaternary records.

\begin{tabular}{llll}
\hline \multicolumn{1}{c}{ Clade } & \multicolumn{1}{c}{ Age } & Location & \multicolumn{1}{c}{ Citation } \\
\hline $\begin{array}{l}\text { Daphnia (Daphnia) and } D . \\
\text { (Ctenodaphnia) }\end{array}$ & Jurassic/Cretaceous & Mongolia & Smirnov, 1992; Kotov and Taylor, 2011 \\
$\begin{array}{l}\text { Simocephalus } \\
\text { Simocephalus (Australia) }\end{array}$ & Jurassic/Cretaceous & Mongolia & Smirnov, 1992; Kotov, 2007; Kotov and Taylor, 2011 \\
$\begin{array}{l}\text { Ceriodaphnia } \\
\text { Ceriodaphnia (Australia) }\end{array}$ & Jurassic/Cretaceous & Mongolia & Smirnov, 1992; Kotov, 2009b \\
Moinia & Jurassic/Cretaceous & NE China, & Lai, 1990; Smirnov, 1992 \\
& & Mongolia & \\
Bosminidae & Eocene & Germany & Lutz, 1991 \\
Chydoridae & Lower Cretaceous & Mongolia & Kotov, 2009b \\
\hline
\end{tabular}

